\title{
CHARACTERIZATION OF THE CONTINENTAL MANTLE IN AN ACTIVE RIFT ZONE: KILBOURNE HOLE, NEW MEXICO
}

\author{
Eric Kappus ${ }^{1}$, Elizabeth Y. Anthony ${ }^{1}$ and Christopher Andronicos ${ }^{1}$ \\ ${ }^{I}$ Department of Geological Sciences, The University of Texas at El Paso, TX 79968, USA
}

\section{INTRODUCTION}

The ultramafic xenoliths at Kilbourne Hole, New Mexico, have played a pivotal role in understanding continental mantle. This is true from the early studies by Irving (1980), in which he characterized bulk rock and mineral chemistry and recognized that peridotites are wall-rocks to veins and dikes of pyroxenite, to recent studies of Os isotopes (Burton and others, 1999; Meisel and others, 2001; Brandon and others, 2002), which document low ${ }^{187} \mathrm{Os} /{ }^{188} \mathrm{Os}$ implying that continental mantle stabilization is as old or older than the age of overlying crustal rocks (Barnes and others, 1999; Barnes and others, 2002). The peridotites documented in these studies, with the exception of a single analysis of harzburgite in Meisel and others, are relatively fertile samples. They have, for instance, $\mathrm{CaO}$ contents of 1.9 to 3.5 weight percent and $\mathrm{Al}_{2} \mathrm{O}_{3}$ of 2.9 to 4.3 weight percent. They have been described as both fine-grained, equigranular and coarse-grained, protogranular in texture. We have collected a suite of less fertile samples that are distinct from the more fertile samples in composition. They have, for instance, 0.6 to 1.3 weight percent $\mathrm{CaO}$ and 0.9 to 1.8 weight percent $\mathrm{Al}_{2} \mathrm{O}_{3}$, and are characterized by a pronounced porphyroclastic texture. Modal analyses of these two groups indicate that the more fertile ones are dominantly lherzolites. The less fertile group includes lherzolite, harzburgite, and dunite. In order to simplify nomenclature in this paper, we refer to this group as olivine-rich peridotite. In addition to the lherzolite and olivine-rich peridotite are pyroxenites, which have been characterized by Irving (1980) and Wilshire and others (1988).

The purpose of the present study is to characterize textures and thermometry for the various lithologies in order to determine their spatial distribution. Our preliminary results suggest that the continental mantle under Kilbourne Hole is chemically and rheologically layered. This observation is based on preliminary thermometry, which shows the lherzolites to be at lower temperatures than the olivine-rich peridotites and earlier studies of Kilbourne Hole samples, which suggest that the fine-grained, equigranular lherzolites may have lower temperatures and pressures than coarse-grained, protogranular ones (Bussod and Williams, 1991).

\section{TEXTURAL CHARACTERIZATION}

There are three distinction textural variants in Kilbourne Hole suite. They are 1) coarse, protogranular, 2) fine-grained equigranular tabular, and 3) porphyroclastic. The first two types were documented originally by Irving (1980), and the third type has not been discussed for the Kilbourne Hole suite. Within our sample suite, the coarse, protogranular and fine-grained equigranular samples are exclusively fertile lherzolites. Also, significantly, composite xenoliths are restricted to the fine-grained, equigranular samples. Irving (1980) made this same observation and interpreted the lherzolites to have been chemically and texturally modified by the injection of pyroxenite veins and dikes.

The porphyroclastic textural group includes samples that are both fertile lherzolites and also the more depleted olivine-rich peridotite. Again, within our sample suite, the olivine-rich peridotite is essentially exclusively porphyroclastic. We have only a single sample whose texture may be described as a coarse, protogranular olivine-rich peridotite.

The three sample suites have textures that indicate they were deformed under varying conditions of strain rate, differential stress and temperature. For instance, the fine-grained equigranular samples have relatively uniform grain size. Many grains are polygonal tabular, with curved grain boundaries. Both olivine and pyroxene exhibit undulatory extinction, subgrains are common, and locally developed mantles of finegrained neoblasts surround pyroxene. These textures suggest that grain boundary coarsening was slow relative to recrystallization suggesting relatively high strain rates for the ambient temperature conditions. In contrast, the coarse protogranular samples have strongly curved grain boundaries and subgrains are less common within olivine. Additionally, mantled porphyroclasts are much more common within this sample suite suggesting that subgrain rotation recrystallization may have been the dominate recrystallization mechanism. Finally, the olivine rich 
peridotites all contain a well- developed porphyroclastic texture. However, the average grain size is larger and grain boundaries are commonly highly curved. Additionally, adjacent pyroxene and olivine often form amoeboid intergrowths. This suggests that phase boundary migration was an important deformation process in this suite. Subgrains are least common within this suite and many of the coarse olivine grains have polygonal $120^{\circ}$ triple junctions suggesting that recovery kept pace with strain rate in these samples. The overall high temperature textures and coarse grain size within the olivine rich peridotites is consistent with the textures developing during melt extraction.

\section{MAJOR/TRACE ELEMENT CHEMISTRY}

The olivine-rich peridotites were initially recognized on the basis of their distinctive porphyroclastic texture and modal compositions. The olivine-rich modes imply that the peridotites are less fertile; elemental chemistry of whole-rock samples and minerals confirm the systematic differences produced by melt depletion (Table 1). This table also highlights the distinctive compositions of the pyroxenites.

Table 1: Geochemistry

\begin{tabular}{|l|l|l|l|}
\hline & Lherzolite & $\begin{array}{l}\text { Ol-rich } \\
\text { peridotite }\end{array}$ & Pyroxenite \\
\hline $\mathrm{CaO}$ & $1.9-3.5$ & $0.6-1.3$ & $16.1-18.1$ \\
\hline $\mathrm{Al}_{2} \mathrm{O}_{3}$ & $2.9-4.3$ & $0.9-1.8$ & $13.5-16.2$ \\
\hline $\mathrm{TiO}_{2}$ & $\begin{array}{l}0.08- \\
0.22\end{array}$ & $0.04-0.08$ & $1.2-1.6$ \\
\hline $\mathrm{MgO}$ & $\begin{array}{l}38.0- \\
41.9\end{array}$ & $45.0-50.0$ & $13.9-15.5$ \\
\hline & & & \\
\hline $\mathrm{Yb}$ & $0.28-0.35$ & $0.04-0.11$ & $1.34-1.58$ \\
\hline $\mathrm{Ni}$ & $1960-$ & $2360-$ & $123-440$ \\
& 2220 & 2590 & $8-112$ \\
\hline $\mathrm{Cr}$ & $2310-$ & $2410-$ & 8 \\
& 2350 & 2950 & \\
\hline
\end{tabular}

Data from Irving (1980), Roden and others (1988), Long (1994).

High-precision neutron activation analyses for three of the olivine-rich peridotites (Long, 1994) indicate that the olivine-rich peridotites have also been metasomatized, This pattern of re-enrichment was also found in some tabular equigranular and composite samples by Roden and others (1988). Their study documented that equigranular and composite samples were variably enriched, while protogranular ones were not. $\mathrm{Sr}$ and $\mathrm{Nd}$ systematics were complex, with many samples having unsupported radiogenic isotopes. The elemental patterns of re-enrichment combined with old but disparate $\mathrm{Sr}$ and $\mathrm{Nd}$ model ages require isolation of this mantle section at least 1 Ga ago, followed by enrichment during the pyroxenite injection event. With the current data, it therefore appears that some equigranular lherzolite and olivine-rich peridotite show the anti-correlation between metasomatism and melt depletion that has been documented in other regions (e.g. McDonough and Frey, 1989). Given that the olivine-rich peridotites appear to lack pyroxenite veins, metasomatism in them is subtle and cryptic compared to the pyroxenite-veined lherzolite.

These patterns of depletion and re-enrichment are particularly intriguing in light of recent studies of Os isotopes for these xenoliths. Burton and others (1999) characterized mineral separates for a single, lherzolite sample. They established that the majority of Os resides in the sulfides, ${ }^{187} \mathrm{Os} /{ }^{188} \mathrm{Os}$ is subchondritic, and interstitial sulfide is in isotopic equilibrium with the whole rock and silicate minerals. Sulfide inclusions and silicates rich in these inclusions yield lower ${ }^{187} \mathrm{Os} /{ }^{188} \mathrm{Os}$ than interstitial sulfide, indicating a multi-stage and ancient lithospheric history for this sample. A previous study of melt and $\mathrm{CO}_{2}$ inclusions for this sample (Schiano and Clocchiatti, 1994) documented final melt temperatures of $1240^{\circ} \pm 20^{\circ} \mathrm{C}$, which is consistent with liquidus temperatures for the trapped melts, and minimum pressures of $1.1 \mathrm{GPa}$. This pressure estimate is consistent with the studies by Bussod and our preliminary data, and supports the hypothesis that the fertile mantle is shallow. Two-pyroxene thermometry for the sample yielded $1120^{\circ} \pm 140^{\circ} \mathrm{C}$, which agrees within error with our preliminary results discussed below.

A second study by Meisel and others (2001) was designed to refine the Os isotopic composition of hypothetical primitive upper mantle. The study is based on samples from a number of localities, including 16 lherzolites $\left(\mathrm{Al}_{2} \mathrm{O}_{3} 2.86\right.$ to 4.29 weight percent) and 1 harzburgite $\left(\mathrm{Al}_{2} \mathrm{O}_{3} \quad 0.92\right.$ weight percent $)$ from Kilbourne Hole and two samples $\left(\mathrm{Al}_{2} \mathrm{O}_{3} 1.37\right.$ to 1.54 weight percent) from San Carlos, Arizona. They find that all localities have a positive correlation for $\mathrm{Al}_{2} \mathrm{O}_{3}$ vs. ${ }^{187} \mathrm{Os} /{ }^{188} \mathrm{Os}$ and that ${ }^{187} \mathrm{Os} /{ }^{188} \mathrm{Os}$ converges on a value of $0.1296 \pm 0.0008$ for fertile compositions. For the samples from Kilbourne Hole and San Carlos, $\mathrm{T}_{\mathrm{RD}}$ $=1.55 \mathrm{Ga}$, which agrees quite well with recent $\mathrm{Nd}$ model ages for crustal basement samples from southern New Mexico and west Texas (Barnes and others, 1999; Barnes and others, 2002). The one harzburgite from Kilbourne Hole falls on the linear correlation of $\mathrm{Al}_{2} \mathrm{O}_{3}$ 
vs. ${ }^{187} \mathrm{Os} /{ }^{188} \mathrm{Os}$, implying that it is, in terms of its Os isotopic signature, continental lithosphere. This result is intriguing in light of recent geophysical studies (LA RISTRA) that document very slow mantle velocities in the axis of the Rio Grande rift (West and others, 2002; Gao and others, 2002).

\section{GEOTHERMOMETRY AND MINERAL CHEMISTRY}

Mineral compositions reflect the systematic changes associated with melt depletion, with $\mathrm{Fo}_{88}$ to $\mathrm{Fo}_{89}$ in the lherzolites vs. $\mathrm{Fo}_{91}$ to $\mathrm{Fo}_{92}$ in the olivine-rich peridotites. Two pyroxene temperatures (Brey and others, 1990; Brey and Kohler, 1990) yield lower temperatures $\left(740-885^{\circ}\right.$ C) for the lherzolites compared to the olivine-rich peridotites $\left(962-1036^{\circ} \mathrm{C}\right)$. The temperature range for lherzolite represents both fine-grained equigranular and porphyroclastic samples. We do not yet have thermometry on protogranular samples. Previous thermometry (Bussod and Irving, 1981; Bussod and Williams, 1991) also found that temperature correlates with textural type, with the finegrained equigranular samples having lower temperatures than the protogranular samples. In addition, they applied the $\mathrm{Ca}$ in olivine barometer and found that the tabular, equigranular samples yielded lower pressures than the protogranular samples. They noted the preliminary status of this barometer and also that some samples showed significant zoning of the $\mathrm{Ca}$, implying thermal resetting. For the one textural type the fine-grained equigranular - included in both the present study and the previous ones, our temperatures are 50 to $100^{\circ}$ lower. We are investigating this discrepancy as part of a larger project to use WDS Xray mapping to assess zoning and target mineral grains best suited to pressure and temperature determinations. At this point, it is significant that both the previous and the current studies document that the fine-grained equigranular samples represent low temperatures and correlations between texture and thermometry suggest mantle layering.

\section{CONCLUSIONS}

The textures of the three distinct textural varieties found at Kilbourne Hole, when combined with the geochemical characteristics of the samples and thermometry suggest that the lithosphere is strongly chemically and rheologically layered. The overall increase in olivine grain size suggests that the finegrained equigranular samples deformed under the conditions of highest differential stress/strain rate consistent with the presence of pyroxenite dikes that intruded into brittle fractures. Using temperature as a proxy for depth suggests that the porphyroclastic olivine rich peridotites evolved at the greatest depth. Interestingly, the overall large grain size within this sample suite suggests that they deformed under the conditions of lowest differential stress/strain rate. This leads to two important conclusions about the lithosphere beneath Kilbourne Hole. The first is that the chemical stratification of the lithosphere at this locality leads to an inverse stratification of density, with the densest rocks at the shallowest levels (sub Moho?). The second is that the fertile fine-grained equigranular samples supported the largest differential stresses. Isotope systematics imply that these textures likely formed during Proterozoic orogenesis and crustal formation, indicating that they may provide important constraints on the vertical distribution of differential stresses within the lithosphere. This, in turn, lends credence to the idea that the Moho is an important stress riser, even during orogenic events.

\section{REFERENCES}

Barnes, M. A., Anthony, E. Y., Williams, I., Asquith, G.B., 2002. The architecture of a $1.38-1.34 \mathrm{Ga}$ granite-rhyolite complex as revealed by geochronology and isotopic and elemental geochemistry of subsurface samples from west Texas. Precambrian Research 119, 9-43.

Barnes, M.A., Rohs, R., Anthony, E.Y., Van Schmus, W.R., Denison, R.E., 1999. Isotopic and elemental chemistry of subsurface Precambrian igneous rocks, west Texas and eastern New Mexico. Rocky Mountain Geology (Special Issue on Proterozoic magmatism) 34, 245-262.

Brandon, A.D., 2002. Osmium isotope evidence for episodic continental lithosphere growth and stabilization over Earth history. EOS Trans. AGU 83(47), Fall Meet. Suppl., Abstract T52D-06.

Brey G.P., Kohler T., Nickel K.G., 1990. Geothermobarometry in four-phase lherzolites I. Experimental results from 10 to $60 \mathrm{~kb}$. Journal of Petrology 31, 1313-1352.

Brey G.P. and Kohler T., 1990. Geothermobarometry in fourphase lherzolites II. New thermobarometers and practical assessment of existing thermobarometers. Journal of Petrology 31, 1353-1378.

Burton, K.W., Schiano, P., Birck, J.-L., Allegre, C.J., 1999. Osmium isotope disequilibrium between 
mantle minerals in a spinel-lherzolite. Earth and Planetary Science Letters 172, 311-322.

Bussod, G.Y. A., Irving, A.J., 1981. Thermal and rheological history of the upper mantle beneath the southern Rio Grande rift: evidence from Kilbourne Hole xenoliths. Conference on the Processes of Planetary Rifting. Napa Valley, CA, pp. 145-148.

Bussod, G.Y. A., Williams, D.R., 1991. Thermal and kinematic model for the southern Rio Grande rift: inferences from crustal and mantle xenoliths from Kilbourne Hole, New Mexico. Tectonophysics 197, 373-389.

Gao, W., Grand, S., West, M., Gok, R., Ni, J., Wilson, D., Aster, R., Schlue, J., Baldridge, S., Semken, S.[RISTRA group], 2002. Mantle dynamics beneath the Rio Grande rift and Colorado Plateau. EOS Trans. AGU 83(47), Fall Meet. Suppl., Abstract S61A-1115.

Irving A.J., 1980. Petrology and geochemistry of composite ultramafic xenoliths in alkalic basalts and implications for magmatic processes with the mantle. American Journal of Science 280A, 389-426.

Long C.A., 1994. Geochemistry of the ultramafic mantle xenoliths from Kilbourne Hole, Potrillo volcanic field, Southern New Mexico. M.S. thesis, The University of Texas at El Paso.

McDonough W.F., Frey F.A. (1989) Rare earth elements in upper mantle rocks. Reviews in Mineralogy 21, 99-145.

Meisel, T., Walker, R.J., Irving, A.J., Lorand, J.-P., 2001. Osmium isotopic compositions of mantle xenoliths: a global perspective. Geochimica et Cosmochimica Acta 65, 1311-1323.

Roden M.F., Irving A.J., Murthy V. R., 1988. Isotopic and trace element composition of the upper mantle beneath a young continental rift: results from Kilbourne Hole, New Mexico. Geochimica et Cosmochimica Acta 52, 461-473.

Schiano, P., Clocchiatti, R., 1994. Worldwide occurrence of silica-rich melts in sub-continental and suboceanic mantle minerals. Nautre, 368, 621624.

West, M. and RISTRA Group, 2002. Structure of the uppermost mantle beneath the RISTRA array from surface waves. EOS Trans. AGU 83(47), Fall Meet. Suppl., Abstract S61A1116.

Wilshire, H.G., Meyer, C.E., Nataka, J.K., Calk, L.C., Shervais, J.W., Nielson, J.E., Schwarzman,
E.C., 1988. Mafic and ultramafic xenoliths from volcanic rocks of the western United States. U.S.G.S. Professional Paper 1443, 179 pp.

Contact: EY Anthony, Department of Geological Sciences, University of Texas at El Paso, El Paso, TX 79968, USA

Email: eanthony@geo.utep.edu 